\title{
PENINGKATAN KEMAMPUAN COPING SELF-TALK MELALUI BIMBINGAN KELOMPOK DENGAN MODEL EXPERIENTIAL LEARNING SISWA KELAS VIII-B SMPN 25 SURABAYA
}

\author{
Vicky Dewi Andieni, Dessy Ameliani Sasika Putri \\ Email: vickydewi21@gmail.com; puth834@gmail.com
}

\begin{abstract}
Abstrak
Penelitian ini bertujuan untuk meningkatkan keterampilan berbicara pada diri siswa melalui bimbingan kelompok dengan model pembelajaran pengalaman. Penelitian ini menggunakan desain penelitian tindakan konseling (PTBK). Subjek penelitian ini adalah 10 siswa yang mengalami self talk coping rendah dan sedang. Analisis data penelitian ini menggunakan reduksi data, penyajian data dan penarikan kesimpulan dan verifikasi.

Hasil analisis data berbicara siswa mengalami peningkatan yang signifikan. Yang terendah dari tahap pra-siklus ke siklus kedua adalah 12\% sedangkan yang terbesar adalah 21\%. Ini berarti bahwa bimbingan kelompok dengan model experiential learning mampu meningkatkan keterampilan berbicara mandiri siswa di kelas VIII-B SMPN 25 Surabaya pada semester ganjil tahun akademik 2018/2019
\end{abstract}

Kata kunci: coping self talk, experiential learning, bimbingan kelompok.

\section{PENDAHULUAN}

Masa Remaja menurut

Marppiare (dalam Wahyuni, 2014) berlangsung antara umur 12 tahun sampai 20 tahun bagi wanita dan 13 tahun sampai dengan 22 tahun bagi pria. Masalah remaja pada fase ini sangat kompleks, dari mulai masalah keluarga, sosial masyarakat maupun pergaulan dengan teman sebaya. Tingginya kecemasan dalam mengungkapkan pendapat tampak saat pembelajaran BK. Diketahui beberapa siswa kelas VIII-B SMPN 25 Surabaya pada saat layanan klasikal BK dengan metode yang biasanya dilaksanakan yaitu ceramah, presentasi dan diskusi kelompok cenderung diam ketika masuk pada sesi tanya jawab.

Keterampilan abad 21 menjelaskan keterampilan yang dibutuhkan siswa yaitu Creativity \& innovation, Critical thinking \& problem solving, Communication dan Collaboration. Siswa yang mampu bertahan salah satunya adalah memiliki komunikasi yang terampil. Sedangkan dalam tugas perkembangan siswa SMP seharusnya mampu mengembangkan pengetahuan dan keterampilan sesuai dengan kebutuhannya untuk mengikuti dan melanjutkan pelajaran dan mempersiapkan karier serta berperan dalam kehidupan masyarakat. 
Pikiran negatif disebabkan oleh adanya percakapan diri (self talk) yang negatif pula. Menurut Corey (2005) dalam teori REBT (Rational Emotif Behavioral Therapy) yang dikembangkan oleh Albert Ellis, Perilaku dipengaruhi oleh Activating Event (A), Belief (B), Emotional Consequences (C) dan Disputing (D). Kejadian yang direkam oleh pikiran menjadi sebuah keyakinan. Keyakinan (Belief) yang kemudian memunculkan Konsekuensi emosional (C). Konsekuensi negatif yang berasal dari keyakinan negatif ini yang diperlukan proses disputing (D). Proses disputing (D) dilakukan melalui Coping SelfTalk, individu dapat mengendalikan percakapan diri (Self-Talk) yang negatif ke positif. Self-talk positif yang telah dibentuk kemudian membuat keyakinan positif dan menggerakkan perilaku positif.

$$
\text { Coping self-talk dapat }
$$

dilakukan melalui berbagai bentuk kegiatan, salah satunya bimbingan kelompok. Bimbingan kelompok lebih efektif dilakukan dikarenakan jumlah anggota kelompok 10-15 siswa. Kegiatan bimbingan kelompok dilakukan dengan model Experiential Learning, model pembelajaran melalui pengalaman sehingga siswa mampu merasakan sesuai dengan masalah yang dialami yaitu kecemasan berpendapat. Experiential Learning dilakukan melalui empat tahap yaitu concrete experience, reflective observation, abstract conceptualization dan active experimentation.

Dari latar belakang yang telah diuraikan, maka penelitian ini diberikan judul "Peningkatan Kemampuan Coping Self-Talk melalui
Bimbingan Kelompok dengan model Experiential Learning Siswa Kelas VIII-B SMP Negeri 25 Surabaya".

Berdasarkan latar belakang masalah tersebut, rumusan masalah penelitian ini adalah sebagai berikut.

1. Bagaimana proses peningkatan kemampuan coping Self-Talk melalui bimbingan kelompok dengan model Experiential Learning Siswa Kelas VIII-B SMPN 25 Surabaya?

2. Bagaimana hasil peningkatan kemampuan coping Self-Talk melalui bimbingan kelompok dengan model Experiential Learning Siswa Kelas VIII-B SMPN 25 Surabaya?

3. Bagaimana respon siswa terhadap kemampuan coping Self-Talk melalui bimbingan kelompok dengan model Experiential Learning Siswa Kelas VIII-B SMPN 25 Surabaya?

Tujuan penelitian ini adalah sebagai berikut.

1. Mendeskripsikan proses peningkatan kemampuan coping Self-Talk melalui bimbingan kelompok dengan model Experiential Learning Siswa Kelas VIII-B SMPN 25 Surabaya.

2. Mendeskripsikan hasil peningkatan kemampuan coping Self-Talk melalui bimbingan kelompok dengan model Experiential Learning Siswa Kelas VIII-B SMPN 25 Surabaya.

3. Mendeskripsikan respon siswa terhadap kemampuan coping SelfTalk melalui bimbingan kelompok dengan model Experiential Learning Siswa Kelas VIII-B SMPN 25 Surabaya. 


\section{Coping Self Talk}

Self-talk adalah berkomunikasi dan berbicara dengan diri sendiri. Selftalk adalah akar permasalahan psikologis yang paling utama. Selftalk yang membentuk kebiasaan, karakter, dan keyakinan seseorang. Tanpa disadari oleh sebagian orang self-talk sama halnya dengan menyugesti dan memprogram alam bawah sadar. Pertama self talk bekerja memprogram alam bawah sadar, kemudian self-talk memengaruhi tindakan, lalu lama-kelamaan tindakan kita tersebut berubah menjadi kebiasaan. Setelah tindakan tersebut menjadi kebiasaan, lama-lama menyatu dengan karakter/sifat, dan setelah menyatu dengan sifat, self-talk awal mulai menjadi realitas dalam kehidupan yang akhirnya membuat seseorang percaya bahwa keyakinan itu memang benar.

Manfaat Berbicara Pada Diri Sendiri (Self Talk) adalah (1) Alat bantu mengambil keputusan, 2) Mengenal diri sendiri, dan (3) Sarana pengendalian diri. Menurut Jones (2012) self-talk terdiri dari dau jenis yaitu negative self talk dan coping self talk. Menurut Zourbanous, dkk (2008) mendeskripsikan bahwa self talk positif dan negatif terbagi menjadi beberapa ciri. Self talk positif mencakup ungkapan kekuatan, kontrol kecemasan, keyakinan, dan instruksi konsentrasi. Sedangkan ciri-ciri self talk negatif yaitu ungkapan cemas, ungkapan ingin melepaskan dan pikiran irrasional.

\section{Bimbingan Kelompok}

Tujuan bimbingan kelompok adalah untuk memandirikan konseli dalam hal mengatur hidupnya, kepercayaan dirinya maupun dalam hal pengambilan keputusan. Tahaptahap bimbingan kelompok menurut Prayitno (1995: 40) yaitu Tahap pembentukan, tahap peralihan, tahap kerja dan tahap pengakhiran.

\section{Model Experiential Learning}

Experiential learning theory (ELT) dikembangkan oleh david kolb sekitar awal 1980 an. Model experiential learning adalah suatu model proses belajar mengejar yang mengaktifkan pembelajar untuk membangun pengetahuan dan keterampilan melalui pengalamannya secara langsung. Experiential learning terdiri dari Tahapan pengalaman nyata, Tahapan observasi refleks, Tahapan konseptualisasi, dan Tahapan implementasi.

\section{METODE PENELITIAN}

Penelitian ini didesain sebagai penelitian tindakan BK (PTBK) dengan dua (2) siklus. Siklus-siklus tersebut terdiri atas empat tahap, yaitu perencanaan, pelaksanaan, pengamatan, dan refleksi yang dilakukan dalam setting bimbingan kelompok dengan model experiential learning. Subjek dalam penelitian ini adalah 10 orang siswa kelas VIII-B SMP Negeri 25 Surabaya yang mengalami self talk rendah dan sedang. Alat pengumpulan data dilakukan dengan nontes berupa angket yang dikembangkan oleh peneliti yang bertujuan untuk mengetahui kemampuan coping self talk siswa dan observasi guna melihat dan mengamati peningkatan maupun perubahan yang terjadi pada siswa, selanjutnya, dilakukan analisa data dengan beberapa tahapan yaitu, reduksi data, penyajian data dan penarikan simpulan. 
HASIL DAN PEMBAHASAN

Hasil Perubahan Coping Self talk pada Siklus I

\begin{tabular}{|c|c|c|c|c|c|}
\hline No & Nama & \multicolumn{2}{|c|}{$\begin{array}{c}\text { Hasil } \\
\text { sebelum } \\
\text { perlakuan }\end{array}$} & \multicolumn{2}{c|}{ Siklus I } \\
\cline { 3 - 6 } & & Skor & Kategori & Skor & Kategori \\
\hline 1 & MEI & 16 & Rendah & 20 & Rendah \\
\hline 2 & TRI & 34 & Sedang & 43 & Tinggi \\
\hline 3 & ZEL & 18 & Rendah & 24 & Sedang \\
\hline 4 & IDA & 20 & Rendah & 28 & Sedang \\
\hline 5 & AMA & 38 & Sedang & 45 & Tinggi \\
\hline 6 & SIT & 28 & Sedang & 34 & Sedang \\
\hline 7 & BRI & 18 & Rendah & 26 & Sedang \\
\hline 8 & RYA & 26 & Sedang & 37 & Sedang \\
\hline 9 & CEL & 20 & Rendah & 28 & Sedang \\
\hline 10 & SAF & 30 & Sedang & 36 & Sedang \\
\hline
\end{tabular}

Berdasarkan hasil tabel tersebut dapat dilihat dari 10 siswa yang menjadi subjek dalam kegiatan layanan bimbingan kelompok model Experiential Learning didapatkan hasil sebelum perlakuan yaitu lima (5) siswa dalam kategori coping self talk rendah dan lima (5) siswa tergolong dalam kategori coping self talk sedang dan belum terdapat siswa yang berada pada coping self talk tinggi. Selanjutnya, setelah dilakukan layanan bimbingan kelompok model Experiential Learning pada siklus I siswa telah mengalami peningkatan coping self talk, namun masih terdapat satu siswa yang masih pada kategori rendah meskipun skor mengalami peningkatan. Selain itu, terdapat 7 siswa yang mengalami peningkatan skor dan berada pada kategori coping self talk sedang. Sedangkan dua siswa telah mengalami peningkatan coping self talk dalam kategori tinggi.

Sedangkan hasil aktivitas guru dan siswa dalam layanan bimbingan kelompok model Experiential Learning pada siklus I memiliki presentase baik, hanya ada beberapa aspek memiliki presentase sedang yaitu pada aspek penggunaan media, peneliti kurang kreatif dalam penggunaan media pada bimbingan kelompok.

Hasil Perubahan Coping Self talk pada

Siklus II

\begin{tabular}{|c|c|c|c|c|c|c|}
\hline \multirow{2}{*}{ No } & Nama & \multicolumn{2}{|c|}{ Siklus I } & \multicolumn{2}{|c|}{ Siklus II } & $\begin{array}{c}\text { Skor } \\
\text { Perubahan } \\
\text { neningkatan }\end{array}$ \\
\cline { 3 - 7 } & & koKategor Skor Kategori & & & & \\
\hline 1 & MEI & 20 & Rendah & 25 & Sedang & 5 \\
\hline 2 & TRI & 43 & Tinggi & 46 & Tinggi & 3 \\
\hline 3 & ZEL & 24 & Sedang & 28 & Sedang & 4 \\
\hline 4 & IDA & 28 & Sedang & 32 & Sedang & 4 \\
\hline 5 & AMA & 45 & Tinggi & 48 & Tinggi & 3 \\
\hline 6 & SIT & 34 & Sedang & 38 & Sedang & 4 \\
\hline 7 & BRI & 26 & Sedang & 30 & Sedang & 4 \\
\hline 8 & RYA & 37 & Sedang & 40 & Sedang & 3 \\
\hline 9 & CEL & 28 & Sedang & 35 & Sedang & 7 \\
\hline 10 & SAF & 36 & Sedang & 42 & Tinggi & 6 \\
\hline
\end{tabular}

Berdasarkan hasil tabel diatas dapat dilihat bahwa pada siklus 2 terjadi peningkatan dari siklus I yaitu 3 dalam kategori tinggi dan 7 berada pada kategori sedang. Untuk yang kategori sedang, terendah adalah MEI dengan skor peningkatan 5 poin dari siklus I skor 20 menjadi siklus II skor 25.

Sedangkan hasil observasi aktivitas guru dan siswa dalam layanan bimbingan kelompok model experiantial learning pada siklus 2 mengalami peningkatan presentase dari siklus I yaitu pada beberapa aspek antara lain melakukan inovasi ice breaking, penggunaan model experiential learning penggunaan media, mengaktifkan siswa berpendapat dan bertanya. Sehingga dari perbaikan yang telah dilakukan pada beberapa aspek tersebut juga mempengaruhi peningkatan coping self talk pada siswa. 
Adapun hasil penelitian tindakan BK (PTBK) ini menunjukkan bahwa layanan bimbingan kelompok model experiantial learning memiliki dampak positif dalam meningkatkan kemampuan coping self talk. Kemampuan ini dapat dilihat dari siswa semakin percaya diri dalam presentasi di depan kelas. Peningkatan tersebut dapat dilihat dari kemampuan siswa dari rendah ke sedang dan tinggi.

Hasil perubahan Coping Self Talk sebelum perlakuan, Siklus I dan Siklus II dari hasil Angket

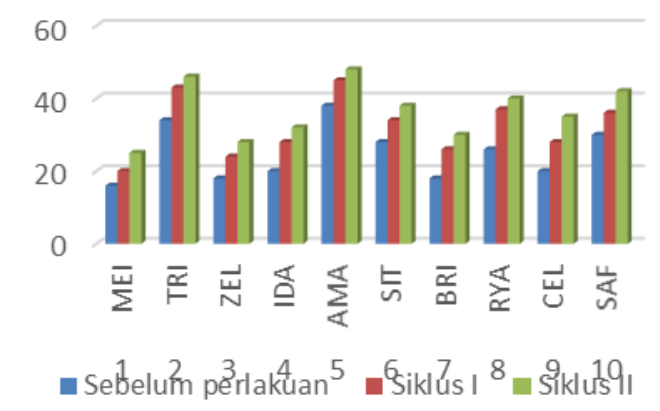

Sedangkan hasil analisis data terkait aktivitas guru dalam layanan bimbingan kelompok model experiential learning yang memiliki pengaruh besar adalah motivasi dalam mengaktifan siswa melalui ice breaking, penggunaan media dalam menarik minat siswa, tahapan bimbingan kelompok dan model experiential learning yang menjadi pokok dalam perubahan kemampuan coping self talk siswa. Dalam proses layanan ini, siswa mulai berani aktif dalam berpendapat dan tanya jawab. Berbeda dengan kondisi sebelum perlakuan.Sedangkan aktivitas siswa selama proses layanan yang terlihat merupakan pengaruh dari coping self talk adalah dalam hal berdiskusi, aktif berpendapat, menanggapi pertanayaan, dan menyampaikan hasil kerja.

\section{KESIMPULAN}

Proses atau tahapan pembelajaran pada siklus I perlu dilakukan perbaikan dengan beberapa solusi di antaranya adalah dengan memberikan motivasi, latihan dan penerapan model experiantial learning kepada siswa selama proses layanan berlangsung.Berdasarkan hasil pengamatan, coping self talk siswa mengalami peningkatan yang cukup signifikan. Terendah dari tahap prasiklus ke siklus II sebesar $12 \%$ sedangkan terbesar yaitu $21 \%$.

Saran penelitian adalah hasil penelitian ini hendaknya dapat digunakan sebagai acuan dalam pengembangan layanan $\mathrm{BK}$ dan dapat dijadikan sebagai salah satu alternatif pemecahan masalah siswa khususnya dalam coping self talk.

\section{REFERENSI}

Arikunto, Suharsimi. 2008. Penelitian Tindakan Kelas. Jakarta: Bumi. Aksara.

Baharudin, \& Wahyuni. 2007. Teori Belajar dan Pembelajaran. Yogyakarta: Ar-Ruzz

Corey, G. 2005. Theory and Practice of Counseling and Psychoterapy, seventh edition. California State University, Fullerton Diplomate Counseling Psychology. American Board of Professional Psychology: Brooks

Jones, R N. 2012. Pengantar Keterampilan Konseling. Yogyakarta: Pustaka Pelajar 
Lestari. 2012. Pengembangan Model Bimbingan Kelompok Dengan Teknik Simulasi Meningkatkan Kecerdasan Emosi Siswa. Jurnal Bimbingan Konseling, Vol 1 No. 2.

Moleong. 2011. Metodologi Penelitian Kualitatif Edisi Revisi. Bandung: PT. Remaja Rosdakarya.

Nayiroh, Badrotun. 2016. Pengembangan Paket Pelatihan Self-Talk untuk Meningkatkan Efikasi Diri Siswa SMPN 21 Malang. Skripsi, Jurusan Bimbingan dan Konseling, Fakultas Ilmu Pendidikan, Universitas Negeri Malang.

Prayitno. 1995. Layanan Bimbingan Dan Konseling Kelompok Dasar Dan Profil. Jakarta: Rineka Cipta.

Simon, Irene Maya. 2011. Penerapan Model Experiential Learning sebagai Strategi untuk Meningkatkan Kemampuan Coping Self-Talk bagi Calon Konselor. Tesis, Jurusan Bimbingan dan Konseling, Program Pascasarjana, Universitas Negeri Malang.

Utami, Hesti Budi. 2015. Pengembangan Panduan Pelatihan Coping Self Talk dengan Model Experiential Learning bagi Siswa SMK Jurusan Keperawatan. Skripsi, Jurusan Bimbingan dan Konseling, Fakultas Ilmu Pendidikan, Universitas Negeri Malang.

Zourbanous, dkk. 2008. Investigating the Functions of self Talk :
The Effect of Motivational Self Talk on Self- Efiicacy and Performance in Young Tennis Players. Sport Psycologist. Vol 22 No.4 